\title{
Late Tortonian bryozoans from Mut Basin, Central Anatolian Plateau, southern Turkey
}

Kamil Zágoršek and Dennis P. Gordon

Acta Palaeontologica Polonica 58 (3), 2012: 595-607 doi: http://dx.doi.org/10.4202/app.2011.0100

Sixteen bryozoan species have been identified in the Başyayla section, Mut Basin, southern Turkey. Five of these species are described here, including two new to science representing new genera: Basyaylella elsae gen. et sp. nov. and Ostrovskia triforamina gen. et sp. nov.

The other three described species (Exidmonea sp., Biflustra savartii, and Margaretta sp.) show unusual features that have not been reported previously. Based on bryozoan data, the Başyayla sequence represents a tropical to subtropical, normal marine environment, with seafloor composed of fine sedimentary particles in a low-energy setting.

Key words: Bryozoa, Cheilostomata, Basyaylella, Ostrovskia, Tortonian, Eocene, Miocene, Mut Basin, Turkey.

Kamil Zágoršek [kamil_zagorsek@nm.cz] Department of Paleontology, National Museum, Vaclavské nam. 68, CZ- 11579 Prague 1, Czech Republic; Dennis P.

Gordon [d.gordon@niwa.co.nz] National Institute of Water \& Atmospheric Research, Private Bag 14901, Kilbirnie, Wellington, New Zealand.

This is an open-access article distributed under the terms of the Creative Commons Attribution License (for details please see creativecommons.org), which permits unrestricted use, distribution, and reproduction in any medium, provided the original author and source are credited. 